The University of Akron

\title{
IdeaExchange@UAkron
}

June 2016

\section{The Documentality of Ethics - Codes of Library Ethics as Support of Professional Practice}

Joacim Hansson

Linnaeus University, joacim.hansson@lnu.se

Please take a moment to share how this work helps you through this survey. Your feedback will be important as we plan further development of our repository.

Follow this and additional works at: https://ideaexchange.uakron.edu/docam

Part of the Business Law, Public Responsibility, and Ethics Commons, Library and Information $\underline{\text { Science Commons, and the Organizational Behavior and Theory Commons }}$

\section{Recommended Citation}

Hansson, Joacim (2016) "The Documentality of Ethics - Codes of Library Ethics as Support of Professional

Practice," Proceedings from the Document Academy: Vol. 3 : Iss. 1 , Article 8.

DOI: https://doi.org/10.35492/docam/3/1/8

Available at: https://ideaexchange.uakron.edu/docam/vol3/iss1/8

This Article is brought to you for free and open access by University of Akron Press Managed at IdeaExchange@UAkron, the institutional repository of The University of Akron in Akron, Ohio, USA. It has been accepted for inclusion in Proceedings from the Document Academy by an authorized administrator of

IdeaExchange@UAkron.For more information, please contact mjon@uakron.edu, uapress@uakron.edu. 


\section{Introduction}

An important part of the etsablishment of any profession is the formulation of ethical standards. Ethical standards is not a sufficient, but a necessary ingredience in what creates social legitimacy for professional practice. Looking at various such practices in medicine, law and business it is clear that professional ethics may be formulated and described in various ways, such as educational texts, practical guidelines or handbooks, and even decretes that defines the boundary of a given institution (Egidius 2001, Long \& Driscoll 2007, Hansson 2016). Today, the most prevalent and authoritative form defining ethical practices within a profession is the ethical code. As such the ethical code may have different degrees of historical and prescriptive significance, where the Hippocratic Oath of medical professions is the perhaps most authoritative, while codes in corporate contexts and in, for instance, librarianship are more advisory and open to practical interpretation (Hauptman 2002, Preer 2008, Buchanan \& Henderson 2009, Besnoy 2009).

The aim of this study is not to make a content analysis of library ethics, but instead focus on codes of ethics, seen as documents. The basic question is thus in what way ethical codes, seen as documents, contribute to the understanding of the practice of professional librarianship. Empirically this is studied through a pars pro toto-inspired analysis of the The Code of Ethics of the American Library Association (ALA), here thus representing library codes of ethics in general. The ALA code is regarded as a suitable choice as it (1) is the first formal ethical code of librarianship, (2) has a clear and transparent history of development through a number of revisions, and (3) is still actively used and looked upon as authoritative not only by the US library professions, but of those around the world as well.

In terms of theory and scientific context, the point of departure is the increasing scholarly literature on documents as socially dynamic, supporting parts of various practices such as design of socio-technical systems (Olsen, Lund, Ellingsen \& Hartvigsen 2012), literature, art and aestetics (Skare 2009, Roux \& Courbières 2014), scientific communication (Frohmann 2004, Francke 2008) and institutional settings, for instance libraries (Hansson 2015, Turner 2015) or museums (Latham 2012). Theoretical discussions on the nature and function of documents ranges from definitions of a document as such (Buckland 1997, Pleshkevich 2010a, 2010b \& 2011, Ferraris 2013) to various conceptual constructions, often grown out of a sociomaterial analytic framework (Lund \& Skare 2010, Irvine-Smith 2015). The common ground of this research provides a foundation for this study regarding the relation between document form (ethical codes), institutional (libraries) and professional (librarianship) practice.

This article is structured in the following way; firstly, the chosen empirical example is described and discussed in relative detail, secondly, the concept of "documentality" is presented and analytically put in relation to the empirical example, and thirdly, conclusions are drawn on significant 
development on the relation between ethical codes and professional practice of librarianship.

\section{Empirical Example: The Code of Ethics of the American Library Association}

Today, there is a plethora of ethical codes of librarianship around the world. In most cases they are formulated on a national level and many are relatively recent, ratified during the latter half of the 20th century (Vaagan 2002). Some codes are tied to specific types of libraries and some are more general, usually upheld by national library associations. There are also documents that are not explicitly defined as ethical codes, but that resembles such both in structure and content. One such example is the UNESCO Public Library Manifesto, first published in 1949, also adopted by the International Federation of Library Associations (IFLA). The Public Library Manifesto was revised in 1994 and in 1999 supplemented with a School Library Manifesto (UNESCO, n.d.). Several other policy formulations and codes of conduct exist today too, sometimes of quite specialized character, such as the the American Society for Information Science and Technology (ASIS\&T) Professional Guidelines and the Code of Ethics for Archivists, issued by the American Society for Archivists . These and several others are analyzed by Anderson (2006), but here attention is given the ethical code for librarians in a strict sense and form.

The relatively recent nature of connecting institutional and professional library practices to ethical codes may seem surprising as the first code of ethics for librarians was formulated and ratified by the ALA already in 1938, and even that after decades of negotiation and reformulation. The fact that the ALA code of ethics was developed during the intense years of defining modern librarianship, not just in the USA but in the world as a whole, makes this a good example to use in an analysis of the documentary function of professional ethical codes as such. Furthermore, not only does it develop in the formatting years of modern library profession, it is also developed in the midst of a society raging with progress and embracing ideals of rationality.

Today the ALA code of ethics is part of the organization's Intellectutal Freedom Manual, now in its 8th edition (Intellectual... 2010). This manual covers several issues concerning libraries of different kinds and their relation to issues such as the freedom to read, preservation and protection of library materials, censorship and freedom of information as constitutionally defined in the USA. As the code of ethics form one chapter in this document, we may consider the Intellectual Freedom Manual a contextual addition to the code itself, which precedes the rest of the manual with 36 years as its first edition was published in 1974. We will return to this later on in this article, but first we need to go back in time to create an understanding of the function of the ethical code as a specific form of document in the early development of modern librarianship. 


\subsection{The Knowles Bolton code}

The most quoted version of the code that eventually was to become the ALA code of ethics was presented by Charles Knowles Bolton in the Annals of the American Academy of Political and Social Science in 1922. It acknowledged the tradition of virtue based ethics that was prevalent in late 19th century librarianship, not least through Melvil Dewey and his sharp criteria for who was suited for the library profession, but emphasised the importance of taking it a step forward as a debt to this first pioneering generation of American librarians and their struggle for professionalization (Garrison, 1979, 186ff). The Knowles Bolton code consists of 30 "canons", or paragraphs, that define areas within the professional practice where ethical issues may become a problem. The "step forward" from the virtue based ideals was instead a focus on the library as an institution of high social legitimacy the library was regarded more important than the librarian.

This forms a sharp contrast against public library pioneer Mary Plummer who, when she in 1903 formulated what is generally considered as one of the first ethical statements of modern librarianship, considered librarianship a calling and the librarian an individual bringing to the profession a gentleman's ésprit de vivre. Her aim was however clear: to advance this higher calling of being a librarian into the realm of modern professions. Her influential work must be seen in parallell to Melvil Dewey's as he advanced the profession from being completely reliant on book into one defined in relation to all kinds of sources to knowledge (Preer, 2001). For Plummer, the key to advancement was the librarian as such, and when she proposed the need for ethical guidlines for librarianship, they all centrered around, as Preer puts it, the individual librarian's "dignity, humility, the willingness to learn, and (...) unostentatious belief in the work of the library" $(2001,6)$. In relation to this, Charles Knowles Bolton attempted to move towards a more neutrally defined professionalism and formulate an alternative view to that of Plummer's in the first version of his ethical code for librarians, published in 1909 in journal Public Libraries.

The version which came to gain full recognition, however, was his revised code which, as mentioned, was published in 1922. Structurally it consists of 30 canons divided into four sections focusing on, in order, the librarian's relation to (1) the trustees, (2) the library staff, (3) other librarians and, lastly, (4) the public (Table 1). 


\begin{tabular}{|c|c|c|c|}
\hline $\begin{array}{l}\text { Librarian's } \\
\text { relation to } \\
\text { trustees }\end{array}$ & $\begin{array}{l}\text { Librarian's } \\
\text { relation to staff }\end{array}$ & $\begin{array}{l}\text { Librarian's } \\
\text { relation to } \\
\text { peers }\end{array}$ & $\begin{array}{l}\text { Librarian's } \\
\text { relation to the } \\
\text { public }\end{array}$ \\
\hline I. Responsibility & $\begin{array}{l}\text { VII. Duty to the } \\
\text { staff }\end{array}$ & $\begin{array}{l}\text { XVII. Expert } \\
\text { advice }\end{array}$ & $\begin{array}{l}\text { XXVI. } \\
\text { Honorarium }\end{array}$ \\
\hline II. Authority & VIII. Permanence & $\begin{array}{l}\text { XVIII. Private } \\
\text { advice }\end{array}$ & $\begin{array}{l}\text { XXVII. Book } \\
\text { selection }\end{array}$ \\
\hline III. Alliances & $\begin{array}{l}\text { IX. Individual } \\
\text { responsibility }\end{array}$ & XIX. Rivalry & $\begin{array}{l}\text { XXVIII. } \\
\text { Specializing }\end{array}$ \\
\hline IV. Loyalty & $\begin{array}{l}\text { X. } \\
\text { Recommendations }\end{array}$ & $\begin{array}{l}\text { XX. engaging an } \\
\text { assistant }\end{array}$ & $\begin{array}{l}\text { XXIX. Relation } \\
\text { to agents }\end{array}$ \\
\hline V. Sincerity & $\begin{array}{l}\text { XI. The staff's duty } \\
\text { to the librarian }\end{array}$ & $\begin{array}{l}\text { XXI. } \\
\text { Predecessors }\end{array}$ & $\begin{array}{l}\text { XXX. } \\
\text { Professional } \\
\text { spirit }\end{array}$ \\
\hline \multirow[t]{5}{*}{$\begin{array}{l}\text { VI. Rejected } \\
\text { measures }\end{array}$} & $\begin{array}{l}\text { XII. The staff's } \\
\text { duty to the library }\end{array}$ & $\begin{array}{l}\text { XXII. A } \\
\text { librarian's } \\
\text { province }\end{array}$ & \\
\hline & $\begin{array}{l}\text { XIII. The work and } \\
\text { the workers }\end{array}$ & $\begin{array}{l}\text { XXIII. } \\
\text { Reputation }\end{array}$ & \\
\hline & $\begin{array}{l}\text { XIV. Personal } \\
\text { obligation }\end{array}$ & $\begin{array}{l}\text { XXIV. Bearing } \\
\text { in public }\end{array}$ & \\
\hline & XV.Health & $\begin{array}{l}\text { XXV. Use of his } \\
\text { name }\end{array}$ & \\
\hline & $\begin{array}{l}\text { XVI. Notice of } \\
\text { resignation }\end{array}$ & & \\
\hline
\end{tabular}

Table 1. Charles Knowles Bolton's ethical code for librarians (1922)

In order to give a picture of how the canons are formulated, canon number IV "Loyalty" can be seen as an example, here in its entirety:

When a librarian cannot, in his dealings with the public, be entirely loyal to a policy which is clearly upheld by his trustees, he should indicate to the public, as far as possible, the reason for this policy without expressing his own opinion; he should also explain his position to the board, and in an extreme case offer to resist. (Knowles Bolton 1922, 141)

Knowles Bolton connects professional librarainship to contemporary social, administrative and organizational trends and developments, stressing rationality and effectivity in the pursuit of professional conduct. The idea of librarianship being a "higher calling" which had permeated previous, virtue 
based, ethical statements and norms was thus left behind. Instead the code is highly prescriptive from an institutional point of view. The librarians is not an individual, but a representative role and function, a professional. With eyes set to the future, Knowles Bolton states that "these canons of ethics stand in the position of counselor to the younger men and women of the profession, combining wordly wisdom with unwordly ideals (Knowles Bolton 1922, 139). Reading this today, we see far more of the former than of the latter, as the code portraits librarianship as far more administrative in character than visionary.

The discussion that followed the publication of the Knowles Bolton code was not uncomplicated. Several issues were at hand: one of the most pressing being the authoritative character of the code itself. In medical professions as well as within law, ratified ethical codes were of such stature that they could - and can - be used as a basis for exclusion of an individual from the community of practitioners. The adherence to professional ethics is important enough to be a significant ingredience defining the professional individual as such. This was never the case in librarianship. Hauptman laments this early on in his treatsie "Ethics of Librarianship" (2002):

"Information specialists do not have to join any organization and even if they do and are caught flagrante delicto, there is nothing ALA or ASIS can do about it. With no way of enforcing their codes, the ruling members of these groups are powerless to castigate, to publish a list of transgressors, or to suggest that someone be sanctioned or fired" (p. 10).

However, he concludes the argumentation, "the disgruntled, the dishonest and the iconoclast risk very little. But this may not be as negative as it may seem" (p.10). We will come back to how this can be a little futher on, but first we need to look at how the ethical code of librarianship itself, as defined by the ALA, has developed since Knowles Bolton's 30 canons.

\subsection{ALA code of ethics, first edition 1938}

In the revised Knowles Bolton code of 1922, the 30 canons are clearly numbered in sequence, while the overall relational themes of its various parts, marked in bold types in Table 1., are described within the running text of the journal article which provide the documentary context. In this way, an explanation of each of the canons is provided, leading from one to another apparently seamless. Each of the canons give concrete direction in a single paragraph on how to deal with the aspect of the relational theme at hand.

The first adoption of this code by the ALA in 1938 have decreased the number of paragraphs from 30 to 28 , and the similarily formulated relational themes of the different parts of the code are clearly emphasised (Table 2.). The individual paragraphs however, are, although numbered I-XXVIII, presented as running text without any head other than the number indicating neither order nor content. 


\begin{tabular}{|l|}
\hline $\begin{array}{l}\text { Preamble } \\
\text { Paragraphs } 1-3\end{array}$ \\
\hline $\begin{array}{l}\text { I. Relation of the librarian to the governing authority } \\
\text { Paragraphs 4-8 }\end{array}$ \\
\hline $\begin{array}{l}\text { II. Relation of the librarian to his constituency } \\
\text { Paragraphs 9-12 }\end{array}$ \\
\hline $\begin{array}{l}\text { III. Relation of the librarian within his library } \\
\text { Paragraphs } 13-19\end{array}$ \\
\hline $\begin{array}{l}\text { IV. Relation of the librarian to his profession } \\
\text { Paragraphs 20-25 }\end{array}$ \\
\hline V. Relation of the librarian to the society \\
Paragraphs 26-28
\end{tabular}

Table 2. ALA code of ethics for librarians, 1938 (Preer 2008, 226-227).

As an example of how the content is formulated, here is paragraph I:5, which corresponds to the "loyalty canon" quoted above in the Knowles Bolton code:

The chief librarian should keep the governing authority informed on professional standards and progressive action. Each librarian should be responsible for carrying out the policies of the governing authority and its appointed executives with a spirit of loyalty to the library. (Preer 2008, 226)

The code is explicitly prescriptive in terms of relations of the librarians towards trustees, staff, peers, the library itself and its users, now defined as "society". Preer concludes that "[the 1938 code] defined the librarian in terms of status and obligation, not function or value" $(2001,11)$. She puts this view of the profession in starch contrast to the rapidly developing society between the wars, not least in terms of relevant technology and shifts of political and social values. The code of ethics was, likely due to lack of contemporary perspective and relevance, ratified without much notice and the ALA did not manage to implement it as an active part of the development of librarianship in all kinds of libraries.

\subsection{Later revisions, 1981,1995 and 2008}

In the years after the implementation of the 1938 code, policy work increased and in 1948 the Library Bill of Rights was published as a sort of "alternative" code of ethics. Several ethics related documents were amended in meetings and by committees of ALA up until the late 1970's as new drafts were published in 1975 and 1979, leading up to a completely revised code of 
ethics in 1981. This revision was significant in that it reduced the number of paragraphs from 28 to 6 , and for the first time refrained from directions and practical recommendations within the various paragraphs. This edition mark a change in the view of the ethical code as a prescriptive document, as it is now officialy a document of general ambition and attitudes focusing general views on censorship, privacy, and the relation between private views and philosophies of the librarian and those of the professional institution. How librarians or libraries should implement the code was now left to their own devices. However, in all the 1981 code of ethics must be seen as just a distilled version of the 1938 edition, and the perspective objectifying "the librarian" is still part of the code. The institution, ALA, formulating the code is by implication bigger than its members, and this provides a certain kind of authoritative claim which is seen as increasingly difficult to uphold, as the ALA never had neither in practical terms nor in ambition, any means to enforce it in a way which the medical or legal professions have. This might be one of the reasons for what is the most visible development in the next edition of the code.

In the 1995 revision, the perspective has suddenly switched, and "the librarian" has now become a "we". Suddenly, in terms of ethical practice, the ALA is the equivalent of its members, the librarians and the libraries. This is an important shift, as it broadens the potential basis for professionals as such and for ethical decision making in institutions and corporations dealing with information in a broader sense. A wider definition of the professional practices relating to the mandate of the ALA is pivotal as the exclusivity of librarians as a single profession in charged is by this time since long challenged by societal and technological development (Anderson 2006).

During the first years of the new millennia, the code was further discussed in the light of rapid technological change. The result was published in 2008 as the now current version of the code was amended (Table 3.).

In relation to the 1995 revision, the one of 2008 can be described as a minor, but not unimportant, update of mainly paragraph IV. Seen from a document prespective both structure and basic function is the the same. What may be interesting to comment upon is the inclusion of the code into the Intellectual Freedom Manual, published by the Intellectual Freedom Office of the ALA (Intellectual... 2010). Here the ethical formulation of professional practice is related to the American constitution and put in context of the wider issue of societal right to intellectual freedom and freedom to information. The code of ethics make up one part of the manual, which is divided as follows: (1) Intellectual freedom and libraries: an overview, (2) Library bill of rights, (3) Protecting the freedom to read, (4) Code of ethics of the American Library Association, (4) Intellectual freedom and the law, (5) Preserving, protecting and working for intellectual freedom. In this document the code of ethics is given a purpose which it may not have had in its early years. By providing this, the statement quoted above by Hauptman that it might not be necessary to strive for an authoritiative character of the ethical code of librarianship such as 
those we find in many other professions seems to make sense. When contextualizing professional ethics not only through a widened professional concept, as was done in 1995, but also within a direction of practice that is related to the very constitution of the USA, it becomes if not legally authoritative so morally binding in a way that covers the central aspects of the complex information reality that provide the bedrock for contamporary professional library practice.

I. We provide the highest level of service to all library users through appropriate and usefully organized resources; equitable service policies; equitable access; and accurate, unbiased, and courteous responses to all requests

II. We uphold the principles of intellectual freedom and resist all efforts to censor library resources

III. We protect each library user's right to privacy and confidentiality with respect to information sought or received and resources consulted, borrowed, acquired or transmitted.

IV. We respect intellectual property rights and advocate balance between the interests of information users and rights holders

V. We treat co-workers and other colleagues with respect, fairness, and good faith, and advocate conditions of employment that safeguard the rights and welfare of all employees of our institutions

VI. We do not advance private interests at the expense of library users, colleagues, or our employing institutions

VII. We distinguish between our personal convictions and professional duties and do not allow our personal beliefs to interfere with fair representation of the aims of our institutions or the provision of access to their information resources

VIII. We strive for excellence in the profession by maintaining and enhancing our own knowledge and skills, by encouraging the professional development of co-workers, and by fostering the aspirations of potential members of the profession

Table 3. Code of ethics of the ALA, rev. 2008

This empirical description now ends, and is continued in the form of a theoretical analysis of the function of the ethical code as a document in relation to the professional practice of librarianship.

\section{Considering ethics as documents}

In an article claiming that social legitimacy for institutions like libraries requires a certain combination of documents, Hansson (2015) argues that the role of documents can be defined in fundamentally two ways; through "constitutive documentality" and "performative documentality". The concept of documentality refers to Ferraris (2013) and his theory of "ontological 
documentality", arguing that documents have a deep philosophical status in defining social institutions in a wide sociological sense of the term. The two types of documentality suggested by Hansson are adaptations of the conceptual couple descriptive/performative documentality in Ferraris (2013, 268-269), relating them to institutions on an organizational practice level rather than a philosophical level. Different forms of documentality make documents work in different ways in organizations. They are also distributed over different kinds of documents. When defining a library's constitutive documentality one may distinguish for instance the professionally organized library catalog, library legislation documents and documents that "institutionally, politically and economically formulate that there actually is a library in existence" (Hansson 2015, 7). Performative documentality is suggested to consist of, amongst others, document types such as policy documents, prescriptive local library plans and codes of ethics. Simply put, constitutive documentality relates to documents addressing what a library is, while performative documentality relates to documents addressing what is done within the library (or any given institution). The two categories are not necessarily mutually exclusive. Some types of documents should be able to fit into both categories of documentality: a library catalog, defined as an autonomous document structure in itself, should be able to be constitutive (without a professionally organized collection we cannot speak of a library) and performative (the development and accuracy of a catalog relates to development in internal and external document and communication infrastuctures).

So, how does one formulate the role of ethical codes as documents, how can their documentality be described? One way is to attempt to highlight some characteristics that can be seen having changed over the course of the time period and the different editions of the ALA code of ethics, that have been on display previously in this article:

- There seems to be a correspondence between a decreased level of detail in the code and an increased level of complexity in the library profession. The Knowles Bolton code prescribes in detail the relation betwen a well defined librarian and his or her professional relations. Looking at the revisions of the ALA code that, symptomatically, come more and more often as society adavances into an increasingly information dependent state, the level of detail decreases. Nothing has like information technology challenged the library profession and widened its scope beyond the traditional confinment of the library and into the information provision and use of society as a whole (Whitworth 2009, Hansson 2010).

- There seems to be an increasing importance over time of a defined documentary context within which the code of ethics is working. In the ALA example the widened conception of professional practice defines 
ethical within the compounds of intellectual freedom. This is at the same time a broadening and a narrowing of the prescriptive documentality of the ethical code, in that it on the one hand is given a role in an overarching set of concepts (freedom of information, right to read etc.) and on the other is provided with a frame of interpretation of its content within the confinements of this set of concepts. This can be seen as a decrease of the code's authoritative autonomy providing a defined kind of legitimacy to the profession, but it may also be seen as an increase of its significance in relation to legislative and constitutional elements, i.e. the constitutive documentality of the library as a social institution, thus obtaining another kind of performative authority. This resembles the development described in Frohmann (2004) and exemplified by Francke (2008) where the role of the scientific article changes with new patterns of scientific communication, when developing technology allows documentary forms that are not necessarily in compliance with the traditional form of the scientific article, but instead rely upon scientific context in order to be defined as scholarly authoritative.

- A third observation that deserves being highlighted is the shift in perspective in the code from objectifying "the librarian" to a "we". This reveals fundamental changes in the role of the code as document. The codification of professional conduct was in the beginning a way to set an ideological and philosophical frame for a well defined traditional profession. In doing this, we see a moving a way from, in an Aristotelian sense, a virtue based ethical standpoint to a deontological, or rule-based, view on ethics. In this, which characterizes the Knowles Bolton code and the ALA codes uptil the revision in 1995, the code of ethic gets if not a function that corresponds to performative documentality, so perhaps more a form of prescriptive documentality the paragraphs in the ethical code stipulated a distinct behavior of the librarian. The perspective seen in latter editions of the ALA codes can be defined as a practice perspective, which in many respects lacks a proper representation in classical ethics. One might define it as a sort of consequetialist ethics in that it is based on two separare, but interlinked phenomena; changes in information technology and the adjustment of professional practice in relation to these. This shift can also help to explain the increasing dependency on surrounding document structures such as commenting literatur, or as in our example, the Intellectual Freedom Manual. Such support literature provide a way to deal with a rapid development in society, in organizations and in professional practice.

Based on these theoretical observations, some conclusions can now be formulated. 


\section{Conclusion}

In their interesting study on the relation between ethical codes and organizational legitimacy, Long \& Driscoll conclude that ethical codes serves more or less one purpose, to "gain support for what the organization is doing by giving the appearence of a close alignment between the persuit of selfinterest and the current values in society" (Long \& Driscoll 2007, 187). This conclusion is interesting in that it concerns organizations with no means to enforce compliance with ethical codes within the organization. Even though self-interest is perhaps not something generally associated with either library orgainizations or librarians as professionals and thus distances this study from theirs, the "position" of the ethical code may seem similar to that described by Long \& Driscoll. Our exclusive focus here, on codes of library ethics, can formulate a distinct value in the fact that it is tied not primarily to the library organization as such but to the profession of librarianship, thus providing a specific texture to the fabric of documents that make up the profession around which the institution, or organization, is built. The relation between the profession and the institution is however constantly adjusting itself, based on external factors such as new technology, new organizational ideals, user relations, and, as suggested by Turner (2015), it may be fruitful to describe these user oriented changes and practices too as documents.

This study has analyzed a general development of ethical codes through one example, the ALA Code of Ethics, and attempted to formulate how the code works in the library organization and in relation to librarianship as a profession. It has been suggested that ethical codes display a performative documentality in that it transmutates in relation to practical considerations on how to tackle environmental and social changes affecting the profession. Changes have been shown that suggest a more or less formal correspondence to general movements in and attitudes towards the profession in society at large, thus making them work as documents by giving not an appearence of, but an actual manifestion of legitimacy and alignment between the profession of librarianship, the library as institution and current values of society.

\section{References}

Anderson, C.G. (2006) Ethical decision making for digital libraries. Oxford: Chandos.

Besnoy, A.L. (2009) Ethics and integrity in libraries. London: Routledge.

Buchanan, E.A. \& Henderson, K.A. (2009) Case studies in Library and Information Science Ethics. Jefferson, NC: McFarland. 
Buckland, M. (1997). "What is a document?". Journal of the American Society for Information Science, Vol. 48 (9), 804-809.

Code of ethics of the American Library Association (n.d.) ala.org/advocacy/proethics/codeofethics/codeethics

Egidius, H. (2011). Etik och profession: $i$ en tid av ökande privatisering och myndighetskontroll. Stockholm: Natur och kultur.

Ferraris, M. (2013) Documentality: why it is necessary to leave traces. New York: Fordham Univ. Press.

Francke, H. (2008) (Re)creations of scholarly journals: document and information architecture in open access journals. Borås/Göteborg: Univ. of Borås/Göteborg University.

Frohmann, B. (2004) Deflating information: from science studies to documentation. Toronto: Toronto Univ. Press.

Garrison, D. (1979) Apostles of culture: the public librarian and American society, 1876-1920. Madison,WN: Univ. of Wisconsin Press.

Hansson, J. (2010) Libraries and identity: the role of institutional self-image and identity in the emergence of new types of libraries. Oxford: Chandos.

Hansson, J. (2015) "Documentality and legitimacy in future libraries: an analytical framework for initiated speculation". New Library World, Vol. 116 $(1 / 2), 4-14$.

Hansson, J. (2016) "On the pre-history of library ethics: documents and legitimacy". Information cultures in the digital age: a Festchrift in honor of Raphael Capurro. Eds: M. Kelly and J. Bielby. Wiesbaden: Springer, 307319.

Hauptman, R. (2002). Ethics and librarianship. Jefferson, NC: McFarland.

Intellectual Freedom Manual (2010). Chicago: American Library Association.

Irvine-Smith, S. (2015) "From object to mediatior: the agency of documents". Proceedings of the Annual Meeting of the Document Academy, Vol. 2, article 2.

Knowles Bolton, C. (1922). "The ethics of librarianship: a proposal for a revised code". Annals of the American Academy of Political and Social Science. Vol. 101, 138-146. 
Latham, K. F. (2012) "Museum object as document: using Buckland's information concepts to understand museum experiences". Journal of Documentation, Vol. 68(1), 45-71.

Long, B.S. \& Driscoll, C. (2007) "Codes of ethics and the pursuit of orgainizational legitimacy: theoretical and empirical contributions". Journal of Business Ethics, Vol. 77, 173-189.

Lund, N. W. \& Skare, R. (2010) "Document theory". Encyclopedia of Library and Information Sciences, Third Edition, 1(1), 1632-1639.

Olsen, B. I.; Lund, N. W.; Ellingsen, G. \& Hartvigsen, G. (2012) "Document theory for the design of socio-technical systems". Journal of Documentation, Vol. 68(1), 100-126.

Pleshkevich, E.A. (2010a) "Formation of the scientific concepts about the documental forms of information; the legal and source-study concepts of a document". Scientific and Technical Information Processing, Vol. 37(4), 217226.

Pleshkevich, E.A. (2010b) "The formation of the scientific concepts about the documental forms of information: the gnoseological and managerial concepts of a document". Scientific and Technical Information Processing, Vol. 37(4), 227-249.

Pleshkevich, E.A. (2011) "Documentation science in the context of the postnon-classical development of modern science". Scientific and Technical Information Processing, Vol. 38(3), 143-147.

Preer, J. (2008). Library ethics. Westport, CT.: Libraries unlimited.

Roux, S. \& Courbières, C. (2014) "Documentary borders: reality or illusion". Proceedings of the Annual Meeting of the Document Academy, Vol. 1, article 11.

Skare, Roswitha (2009) "Complementarity: a concept for document analysis?". Journal of Documentation, Vol. 65(5), 834-840.

Turner, D. (2015) "Reconsidering library collections: community services as documents". Proceedings from the Annual Meeting of the Document Academy, Vol. 2, article 17. 
UNESCO Public library Manifesto (n.d.),

http://www.unesco.org/webworld/libraries/manifestos/libraman.html (feb 2016)

Vaagan, R.W. (2002) The ethics of librarianship: an international survey. München: K.G. Saur.

Whitworth, A. (2009) Information obesity. Oxford: Chandos. 